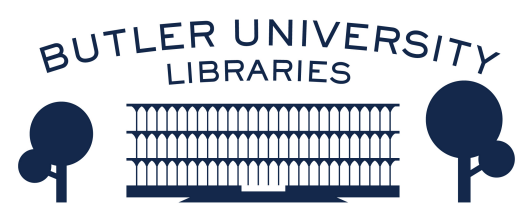

Journal of Hindu-Christian Studies

Volume 15

Article 4

January 2002

\title{
Introductory Information and Introduction
}

Bradley Malkovsky

Follow this and additional works at: https://digitalcommons.butler.edu/jhcs

Part of the Religion Commons

\section{Recommended Citation}

Malkovsky, Bradley (2002) "Introductory Information and Introduction," Journal of Hindu-Christian Studies: Vol. 15, Article 4.

Available at: https://doi.org/10.7825/2164-6279.1271

The Journal of Hindu-Christian Studies is a publication of the Society for Hindu-Christian Studies. The digital version is made available by Digital Commons @ Butler University. For questions about the Journal or the Society, please contact cbauman@butler.edu. For more information about Digital Commons @ Butler University, please contact digitalscholarship@butler.edu. 


\section{EDITORS}

EDITOR: Bradley J. Malkovsky

232 Malloy Hall

University of Notre Dame

Notre Dame, IN 46556 USA

Email: hcsb.1@nd.edu
CO-EDITOR: Anand Amaladass

Institute of Philosophy and

Culture

81 Lattice Bridge Road

Thiruvanmiyur, Madras

INDIA 600041

EDITOR'S ASSISTANT: Sally A. Burns

\section{EDITORIAL ADVISORY BOARD}

\section{R. Balasubramanian}

University of Pondicherry

Klaus Klostermaier

University of Manitoba

Francis X. Clooney, S.J.

Boston College

Julius Lipner

University of Cambridge

John Carman

Harvard Divinity School

U. R. Anantha Murthy

Mahatma Gandhi University

Margaret Chatterjee

Westminster College, Oxford
Raimundo Panikkar

University of California, Santa Barbara

S. Cromwell Crawford

University of Hawaii at Manoa

David C. Scott

United Theological College

J.T.K. Daniel

Serampore College

R. Vijayalakshmi

International Institute for Tamil Studies

Diana Eck

Harvard University

Bibhuti Yadav

Temple University

\section{EDITORIAL POLICY}

The Hindu-Christian Studies Bulletin is an annual scholarly journal published jointly at the University of Notre Dame and at the Institute of Philosophy and Culture, Madras, India. It is the official publication of the Society for Hindu-Christian Studies.

The aim of the Bulletin is to create a worldwide forum for the presentation of Hindu-Christian scholarly studies, book reviews, and news of past and upcoming events. Materials selected for publication will be balanced between historical research and contemporary practice and, where possible, will employ analytical and theoretical analysis set within the context of our shared contemporary experience. Contributions are invited and may be addressed to either the Editor or the Co-Editor. Articles of 3000-3500 words are preferred. Send manuscript in paper form as well as on diskette. A style sheet is available on request. The Bulletin adopts a policy of non-gender specific language where applicable. All articles are subject to review before acceptance and may receive editorial modification in the course of publication.

\section{SUBSCRIPTION INFORMATION}

An annual subscription is included with membership in the Society for Hindu-Christian Studies. Membership annual dues: US dollars $\$ 31$; students US dollars $\$ 15$; special 3-year rate: US dollars $\$ 75$. Subscription only rates (individuals and institutions): US dollars $\$ 12$; Overseas address: US dollars $\$ 13$. Single copies of back issues: US dollars $\$ 10$. No other currencies can be accepted. Make check or money order in US dollars payable to the Society for Hindu-Christian Studies and mail to Bradley Malkovsky at the address above. For subscription information within India, please write to Anand Amaladass, at the address above. The Bulletin is indexed in the ATLA Religion Database, published by the American Theological Library Association.

HINDU-CHRISTIAN STUDIES BULLETIN

(C)2002 Hindu-Christian Studies Bulletin

ISSN 0844-4587 


\section{EDITOR'S INTRODUCTION}

IN the previous issue of the Hindu-Christian Studies Bulletin Harold Coward, the Bulletin's founder and editor, announced the impending relocation of this journal from the University of Victoria, Canada to the University of Notre Dame, U.S.A. and the transition to myself as new editor. Through the generous support of Notre Dame the move took place in August 2001. The Bulletin will remain true to the vision of its founder: "to create a world-wide forum for the presentation of Hindu-Christian scholarly studies, book reviews and news of past and upcoming events." To the best of my knowledge, the Hindu-Christian Studies Bulletin is the only scholarly publication in the world devoted exclusively to the encounter of Hindu and Christian thought, spirituality and socio-political issues.

The main theme of the 2002 issue is the controversy over the meaning and legitimacy of mission and religious conversion, a topic that has received increased attention in both the western and Indian media in recent years. In his opening essay on the subject Michael Amaladoss notes the controversial nature of conversion in the history of India as individuals and groups converted from Hinduism to Buddhism, Jainism, Islam, Sikhism and Christianity and sometimes were reconverted. He points out that conversions are not just spiritual acts, but are also events with psychological, social, cultural, economic and political aspects. He offers a number of factors that have motivated people to change religious or social identity, and the emphasis throughout his essay is that the free decision of any individual to convert to another religion should be respected by all. He argues that adherence to the principles of India as a secular republic should support this attitude and preclude conversion from becoming a political problem.
Arti Dhand follows with an examination of the Mahabharata's attitude to other faiths to see what light this might shed on the contemporary situation. She summarizes how the Mahabharata responded to foreign ideas in both positive and negative ways. For example, the Jain teaching of nonviolence was reformulated to make possible its integration into a new Hindu context. By contrast, the Mahabharata rejected the Buddhist teaching of no-self and the repudiation of the Veda as erroneous doctrines. But in these and other instances violence was never advocated as an acceptable method for the advancement of one,s own views or the restriction of others. Dhand argues that the Mahabharata recognized a certain merit even in opposing views and embraced a broadminded tolerance of different forms of belief. She observes that it is the high ideal of Hindu history to absorb what is best from other traditions and not to persecute those whose doctrines are rejected. Coercion of the weak by the strong has no place in the Mahabharata.

Judson Trapnell interprets the controversy concerning evangelization and conversion as a conflict between stories and images of India promoted by four very different groups, two of them Hindu and two Christian. Conservative Hindu nationalists interpret Christian attempts at conversion in light of the image of India as Mother Goddess whose Hindu children are expected to protect her sacredness and purity from outside defilement. More secularist Hindus, by contrast, adhere to an image of India as a land with a long tradition of religious diversity and tolerance. The Jain teaching on the many-sidedness of truth, the BhagavadGita's formulation of very different yet valid paths of spirituality, the Buddhist emperor Ashoka's policy of religious tolerance, and the more modern recognition of truth in other traditions by Ramakrishna, 
Vivekananda and others - all these witness to a long-standing attitude of tolerance and religious diversity from which the West could learn. A third position is taken by Evangelical Christian missionaries who work within the narrative of India as a spiritual battleground. Here India and Hinduism are associated with darkness and the rule of Satan, in continual combat with Christ, who is the light of the world, whose body on earth is the Church, and who commands his followers to missionize. The fourth and final approach to evangelization and conversion is taken by Roman Catholic theologians in India who embrace a theology of liberation. India is now seen as the land of the marginalized, the oppressed, and the poor. In this context evangelization is interpreted not as the conversion of people from one religion to another, but rather as the conversion of all - both Christian and Hindu - to the Gospel values of dialogue, justice, freedom and community. These theologians recognize similar socio-political and spiritual ideals and values in other religions, and they advocate a mutual collaboration and enrichment of India's varied traditions toward the common goal of holistic liberation.

Anantanand Rambachan concludes the discussion on conversion by noting that exclusivistic and inclusivistic approaches to religious diversity have long existed among both Hindus and Christians. Yet what has been characteristic of the Hindu approach to conversion was the acknowledgement that there are multiple ways of being religious, and that those individuals involved in doctrinal dispute, whether Hindu, Buddhist or Jain, frequently shared important elements of a common worldview. Moreover, the disputes were dialogical in nature; militarism and triumphalism were eschewed, and no concerted attempt was made to eliminate other religions altogether. Christian mission in the modern era, by contrast, was linked to Western colonialism, imperialism and arrogance. It often enough attempted to completely supplant other religions and showed little regard for Indian. culture and social customs. It is this fact more than any other that has contributed to a widespread Hindu resentment and distrust of Christianity. But here, Rambachan argues, a stereotyping of Christianity emerges that overlooks diversity in its understanding of mission and fails to understand the attractiveness of Christianity to the Hindu convert, especially for those of the untouchable castes. $\mathrm{He}$ suggests that Hinduism must be challenged to recognize why some of its members become disillusioned and turn to the Gospel proclamation of the inclusive love of God and the ideal of a community seeking human dignity and equality.

Bradley Malkovsky
University of Notre Dame

Notes

1. Harold Coward, "Introducing the Bulletin," Hindu-Christian Studies Bulletin 1 (1988): 1. 